\title{
Nutritional and functional characterization of wild and cultivated Sarcocornia neei grown in Chile
}

\author{
Javiera Riquelme ${ }^{1}$, José Antonio Olaeta ${ }^{1}$, Lena Gálvez ${ }^{2}$, Pedro Undurraga ${ }^{1}$, \\ Claudia Fuentealba ${ }^{1}$, Andrea Osses ${ }^{3}$, Jaime Orellana ${ }^{3}$, José Gallardo ${ }^{3}$, and \\ Romina Pedreschi ${ }^{1}$ \\ ${ }^{1}$ Pontificia Universidad Católica de Valparaíso, Facultad de Ciencias Agronómicas y de los Alimentos, \\ Escuela de Agronomía. Calle San Francisco s/n, Quillota, Chile. \\ ${ }^{2}$ Pontificia Universidad Católica de Valparaíso, Facultad de Ciencias Agronómicas y de los Alimentos, \\ Escuela de Alimentos. Av Waddington 716, Playa Ancha, Valparaíso, Chile. \\ ${ }^{3}$ Pontificia Universidad Católica de Valparaíso, Escuela de Ciencias del Mar, Ave. Altamirano 1480, \\ Valparaíso, Chile.
}

\begin{abstract}
J. Riquelme, J.O. Olaeta, L. Gálvez, P. Undurraga, C. Fuentealba, A. Osses, J. Orellana, J. Gallardo, and R. Pedreschi. 2016. Nutritional and functional characterization of wild and cultivated Sarcocornia neei grown in Chile. Cien. Inv. Agr. Cien. Inv. Agr. 43(2): 283-293. Sarcocornia neei is a halophyte that grows on the coast of the Valparaiso Region of Chile. Studies related to its nutritional and functional value under wild and cultivated conditions are not available. Thus, in this study, a nutritional (complete proximal, mineral and dietary fiber analysis) and functional characterization (total phenolics, $\beta$-carotene, hydrophilic and lipophilic antioxidant activity (HAA and LAA) and ascorbic acid) were performed for wild and cultivated plants. Wild plants displayed higher amounts of compounds involved in stress defense mechanisms such as total phenolics, proteins, dietary fiber and ash. The mineral analysis revealed that $\mathrm{Na}^{+}$and $\mathrm{Cl}^{-}$are the main ions accumulated in wild and cultivated Sarcocornia neei that are present in significantly higher amounts in the cultivated plants. The functional characterization revealed higher amounts of dietary fiber, total phenolics and HAA in wild plants than in cultivated plants. Similar contents of $\beta$-carotene, LAA and ascorbic acid were found for wild and cultivated plants. The results from this study provide information on the potential of Sarcocornia neei to be consumed as a leafy green vegetable with important amounts of main nutrients and functional metabolites.
\end{abstract}

Key words: antioxidant, dietary fiber, proximal analysis, seawater, sustainability

\section{Introduction}

Globalization and the standardization of food production systems worldwide threatens food diversity, a phenomenon known as 'nutrition

Received October 14, 2015. Accepted March 3, 2016. Corresponding author: romina.pedreschi@pucv.cl transition,' and it has resulted in simplified diets that have replaced plant and animal food sources with a limited number of highly caloric foods. This phenomenon is highly correlated with the increase in chronic diseases such as diabetes, obesity, and cancer (Johns and Eyzaguirre, 2006). 
The introduction of a diet of non-conventional plant-based foods with desirable nutritional and functional components that can be produced using non-scarce inputs (seawater, aquiculture waste and/or poor soils) is an innovative strategy to diversify and increase food availability. Halophytes are plants that can grow in areas exposed to high salinity such as seawater-immersed areas (Flowers and Colmer, 2008). Some species of halophytes have been used as forage (Bustan et al., 2005), in phytoremediation (Manousaki and Kalogerakis, 2011), as a renewable energy source (Eganathan et al., 2006), as ornamental plants (Zia et al., 2008), and as gourmet vegetables (Ventura et al., 2011).

Sarcocornia neei, known as 'sea asparagus', is a halophytic perennial shrub that belongs to the Amaranthaceae family (former Chenopodiaceae). It grows in erect or horizontal form, and the green and succulent shoots reach $0.2 \mathrm{~m}$ in height (Scott, 1978). Due to the limited number of studies related to the nutritional and functional potential of Sarcocornia, it is often compared or associated with Salicornia. These two genera present similar morphological characteristics and mainly differ in the growth habit, e.g., perennial vs. annual for Sarcocornia and Salicornia, respectively (Davy et al., 2006). Important amounts of crude protein (21.5-24\% DW), ascorbic acid (6 mg $\left.100 \mathrm{~g}^{-1} \mathrm{FW}\right)$ and $\beta$-carotene $\left(15.96 \mathrm{mg} 100 \mathrm{~g}^{-1} \mathrm{FW}\right.$ ) comparable with the amounts present in leafy vegetables such as spinach (Proteggente et al., 2002) have been reported for Salicornia by Lu et al. (2010). The total polyphenol content of different species of Sarcocornia (2 $\mathrm{mg} \mathrm{GAE} \mathrm{g}^{-1} \mathrm{FW}$ ) (Ventura et al., 2011) is higher than that of frequently consumed leafy vegetables that are considered to have a high total polyphenolic content (values $>0.5 \mathrm{mg}$ GAE $\mathrm{g}^{-1} \mathrm{FW}$ ) (Isabelle et al., 2010). Both Sarcocornia and Salicornia are rich sources of polyunsaturated fatty acids ( $\alpha$-linolenic, $\omega 3$ and $\alpha$-linoleic, $\omega 6)$ with approximate values of 2.2 and $1.73 \mathrm{~g}$ $100 \mathrm{~g}^{-1} \mathrm{DW}$, respectively. A significant amount of ions is accumulated by the plant especially $\mathrm{Na}^{+}$

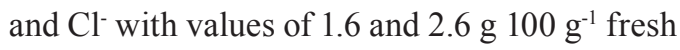
edible tissue (Ventura et al., 2011).
To the best of our knowledge, there is no complete study to date reporting the nutritional and functional potential of the species $S$. neei present in South America. Thus, the main aims of this research were (i) to characterize nutritionally the aerial succulent shoots of $S$. neei grown in wild and cultivated conditions and (ii) to conduct a functional characterization of the aerial succulent shoots of wild and cultivated $S$. neei grown in the Valparaiso region of Chile.

\section{Materials and methods}

\section{Plant material and growing conditions}

Wild $S$. neei material was collected from Salinas de Pullally (Valparaíso, Chile; latitude, $32^{\circ} 24^{\prime} 50.72^{\prime \prime} \mathrm{S}$; longitude, $71^{\circ} 23^{\prime} 35.01^{\prime \prime} \mathrm{W}$ ) with an average temperature of $13-22{ }^{\circ} \mathrm{C}$, annual precipitation of $315 \mathrm{~mm}, 10-14.3 \mathrm{~h} \mathrm{~d}^{-1}$ light and relative humidity of 44-82\% (Viña del Mar Airport Weather Conditions). Aerial succulent shoots (1 $\mathrm{kg}$ per biological replicate) of approximately 10 $\mathrm{cm}$ were cut and immediately frozen in liquid nitrogen and stored at $-80{ }^{\circ} \mathrm{C}$. In total, 2500 cuttings of $S$. neei with a lignified base were placed in expanded polystyrene trays and destined to develop roots in seawater tanks for 4 weeks. Then, the cuttings were transplanted to boxes $(70 \times 70$ $\times 30 \mathrm{~cm}$ ) containing soil from Laguna Verde and irrigated with $20 \mathrm{~L} \mathrm{~d}^{-1}$ of seawater. These boxes were placed under a plastic semitransparent roof. The chemical characterization of the seawater and soil was performed by the Soil Laboratory of Pontificia Universidad Católica de Valparaíso, Chile. Forty-eight plants were symmetrically arranged in each box ( 67 plants $\left.\mathrm{m}^{-2}\right)$. After 17 weeks, cultivated plants $10-15 \mathrm{~cm}$ in height grown at average temperatures of $13-22{ }^{\circ} \mathrm{C}$ and $44-82 \%$ relative humidity (Viña del Mar Airport Weather Conditions) were cut and immediately frozen in liquid nitrogen for further characterization. A total of four biological replicates comprising 35 shoots were collected for each, the wild and cultivated material. 


\section{Nutritional characterization}

Proximal analysis. The proximal analysis included (g $100 \mathrm{~g}^{-1} \mathrm{FW}$ ) moisture (AOAC, 1984)), protein (AOAC, 1984), lipids (AOAC /NC 14019 (1984) modified), ash (AOAC, 1990), crude fiber (Schmidt-Hebbel, 1981), nitrogen-free extract (NFE) by difference and calories.

Mineral analysis. The mineral analysis of the edible wild and cultivated shoots included N (g 100 $\mathrm{g}^{-1} \mathrm{FW}$ ), $\mathrm{Pb}, \mathrm{Cd}$ and $\mathrm{As}$ ( $\mathrm{mg} \mathrm{kg}^{-1} \mathrm{FW}$ ) according to the methods described by Sadzawka et al., (2007). $\mathrm{P}, \mathrm{K}, \mathrm{Ca}, \mathrm{Mg}, \mathrm{Na}$ (g $\left.100 \mathrm{~g}^{-1} \mathrm{FW}\right), \mathrm{Zn}, \mathrm{Mn}, \mathrm{Fe}, \mathrm{Cu}$, and $\mathrm{B}\left(\mathrm{mg} \mathrm{kg}^{-1} \mathrm{FW}\right)$ was determined according to the methodology described by Sadzawka et al. (2004). $\mathrm{Cl}^{-}\left(\mathrm{g} 100 \mathrm{~g}^{-1} \mathrm{FW}\right.$ ) was determined with the method of Sadzawka (2006).

Dietary fiber. Dietary fiber was determined according to the official method AOAC 985.29 (1997) with some modifications. Dried samples were ground and passed through a mesh screen. One gram of sample was weighed in a beaker. A phosphate buffer $(\mathrm{pH}=6.0)$ was added to each beaker and mixed. Then, $\alpha$-amylase was added, and the beaker was placed in a boiling water bath. Subsequently, the $\mathrm{pH}$ was adjusted to 7.5. A protease solution was added and placed in a water bath with agitation. The $\mathrm{pH}$ was adjusted to 4-4.6, and amyloglucosidase was added and placed in a water bath with agitation. Then, $95 \%$ ethanol was added, and the solutions were placed overnight. Subsequently, the solution was vacuum filtered and the residue was washed with $78 \%$ ethanol, 95\% ethanol and acetone. Finally, the papers were dried. The results are expressed as $\mathrm{g}$ dietary fiber $100 \mathrm{~g}^{-1}$ of sample in DW.

\section{Functional characterization}

Total phenolics (TP). Total phenolics were determined according to the method of Shetty et al. (1995). Samples were extracted and prepared according to the method of Chen et al. (2008) with some modifications and also used to test the HAA. Briefly, a dried sample was homogenized with $95 \%$ methanol and shaken. The solution was centrifuged, and the supernatant was removed to another container, shaken and centrifuged twice with $80 \%$ methanol. The methanol was evaporated by rotary evaporation. The extract was re-suspended with distilled water, and the $\mathrm{pH}$ was adjusted to 7 . Five hundred $\mu \mathrm{L}$ of Sarcocornia extract was transferred into a test tube and mixed with $95 \%$ ethanol and water. Folin-Ciocalteu reagent $(1 \mathrm{~N})$ was added to each sample, which was then vortexed. After 5 min of dark incubation, $5 \% \mathrm{Na}_{2} \mathrm{CO}_{3}$ was added, and the mixture was allowed to stand for $1 \mathrm{~h}$ in the dark. The absorbance was read at $725 \mathrm{~nm}$. The standard curve was established using 10 to $200 \mu \mathrm{g} \mathrm{mL}^{-1}$ of gallic acid in $95 \%$ ethanol, and the results are expressed as $\mathrm{mg}$ of gallic acid equivalents (GAE) $100 \mathrm{~g}^{-1}$ of sample in DW.

$\beta$-carotene. $\beta$-carotene was determined according to the methodology described by Reyes et al. (2007) with some modifications. The extract sample was also used to test the LAA. Carotenoids were extracted from the sample by homogenizing with acetone:ethanol (1:1) containing BHT (butylated hydroxytoluene). The homogenate was filtered and washed with the solvent and diluted using the extraction solvent. Then, hexane was added, shaken and allowed to stand for $15 \mathrm{~min}$, and water was added and shaken; separation of the phases was allowed to occur for $30 \mathrm{~min}$. The spectrophotometer was blanked with hexane, and the absorbance of samples was measured at $470 \mathrm{~nm}$. $\beta$-carotene was quantified using a $\beta$-carotene standard curve $\left(1-4 \mu \mathrm{g} \mathrm{mL}^{-1}\right)$. The results are expressed as $\mathrm{mg} \beta$-carotene $\mathrm{g}^{-1}$ of sample in DW.

Hydrophilic and lipophilic antioxidant activity. DPPH (2,2-diphenyl-1-picrylhydrazyl) HAA and LAA were determined according to the methods of Chen et al. (2008) and Reyes et al. (2007), respectively, with some modifications. Samples were analyzed in triplicate. A work 
solution (2.5 mg DPPH $100 \mathrm{~mL}^{-1}$ methanol) was added to the sample extract. The decrease in the absorbance was monitored after $25 \mathrm{~min}$ at $517 \mathrm{~nm}$. The absorbance of a control (water and methanol for HAA and LAA, respectively) was also recorded after $25 \mathrm{~min}$ at the same wavelength. The percentage of inhibition was calculated, and the antioxidant capacity is expressed as $\mu \mathrm{mol}$ Trolox equivalents (TE) $100 \mathrm{~g}^{-1}$ sample DW using a standard curve of Trolox in methanol 20 - $160 \mu \mathrm{M} \mathrm{mL}^{-1}$.

Ascorbic acid content. Ascorbic acid was extracted according to Odriozola-Serrano et al. (2007). Briefly, lyophilized samples (0.1 g) and 4.5\% metaphosphoric acid were homogenized. The samples were centrifuged and vacuum filtered. A HPLC system series 200 with a UV/vis detector (Perkin-Elmer Inc., Shelton, CT, USA) equipped with a binary pump and an autosampler and controlled by TotalChrom software (Perkin-Elmer Inc., Shelton, CT, USA) was used. The analytical column was $\mathrm{C}_{18}$ Spherisorb ODS2 $(5 \mu \mathrm{m} ; 4.6 \mathrm{~mm} \times 250 \mathrm{~mm})$ (Merck, Darmstadt, Germany). The injection volume was $20 \mu \mathrm{L}$, the flow rate was $1 \mathrm{~mL}$ $\mathrm{min}^{-1}$, and the eluates were monitored at 245 $\mathrm{nm}$ at $20{ }^{\circ} \mathrm{C}$. The mobile phase comprised 0.1 $\mathrm{M}$ sodium acetate $(\mathrm{pH}=4.25)$. Standard solutions of ascorbic acid (Sigma Chemical Co.) were prepared in concentration levels from 0.6 to $30 \mu \mathrm{g} \mathrm{mL}^{-1}$. The results are expressed as $\mathrm{mg}$ of ascorbic acid per $\mathrm{g}$ of sample DW.

\section{Statistical analysis}

A completely randomized design was used, and it comprised two treatments (wild vs cultivated) with four biological replicates each. The data were analyzed by a $t$-test comparison of independent means using the statistical program Minitab 17. Differences were considered significant at $\mathrm{P} \leq 0.05$.

\section{Results}

\section{Proximal analysis}

The moisture and protein contents were significantly higher in wild plants $(\mathrm{P} \leq 0.05)$ than in cultivated plants while lipids, NFE and calories displayed no significant differences. The ash and crude fiber content were significantly higher in cultivated plants $(\mathrm{P} \leq 0.05)$ than in wild plants (Table 1$)$.

\section{Mineral analysis}

Macronutrients: $\mathrm{Cl}, \mathrm{Na}, \mathrm{K}, \mathrm{N}$, and $\mathrm{Mg}$ were observed as major minerals. Fe and $\mathrm{Mn}$ were observed as major micronutrients. The contaminants $\mathrm{Cd}, \mathrm{Pb}$ and As were found in wild and cultivated plants but in different amounts. The $\mathrm{Cd}$ and As values were under the maximum values determined by the sanitary regulation of food from Chile, but $\mathrm{Pb}$ was beyond the limits (Adiveter, 2005).

Table 1. Proximal analysis of wild and cultivated Sarcocornia neei plants grown in Valparaíso.

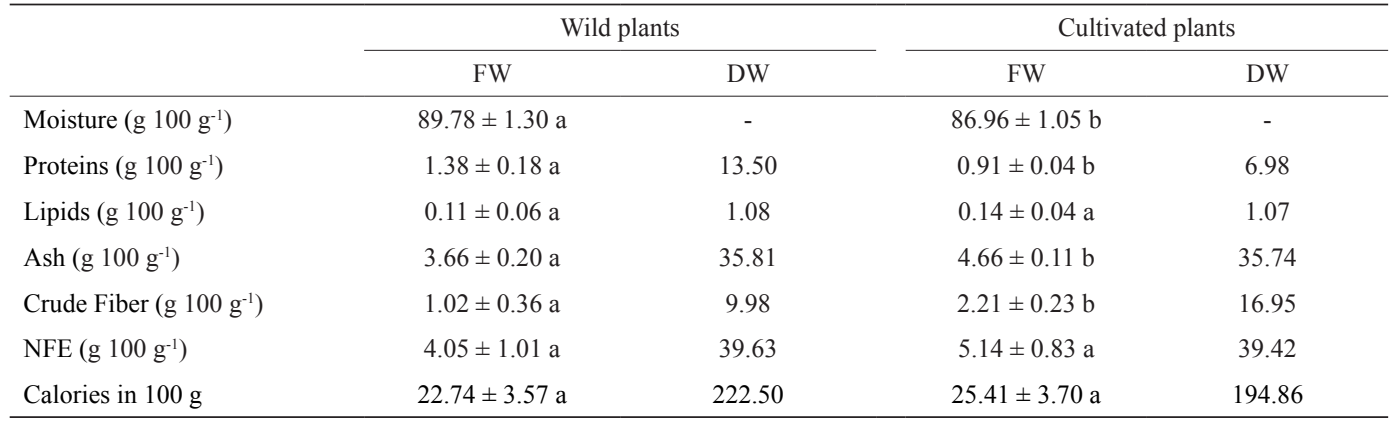

Data are expressed as the means of four repetitions. Different letters in vertical columns indicate significant differences $(\mathrm{P} \leq 0.05)$. 
All of the minerals were found to be significantly higher in wild plants compared with cultivated plants corresponding to $\mathrm{N}, \mathrm{K}, \mathrm{Ca}, \mathrm{Mg}, \mathrm{Mn}, \mathrm{Pb}$ and As (Table 2). Similar contents of P, Zn, Fe, $\mathrm{Cu}$ and $\mathrm{Cl}$ were found for both wild and cultivated plants while higher $\mathrm{B}, \mathrm{Na}, \mathrm{Cd}$ contents were found in cultivated plants than in wild plants (Table 2).

\section{Functional characterization}

The dietary fiber, total phenolics and HAA levels in wild plants were considerably higher than in cultivated plants of $S$. neei. The $\beta$-carotene, LAA, and ascorbic acid levels were found to be similar in wild and cultivated plants, with no significant differences (Table 3).

\section{Discussion}

\section{Nutritional characterization}

S. neei can be considered as a potential leafy vegetable species due to its high water content and composition as shown in the proximal analysis (Table 1). Its water content (85.95) is comparable with that of other common green leafy vegetables (94.91) such as celery, parsley, cabbage and lettuce (Caunii et al., 2010). Exposure to salinity increases the succulence of plants such that ions accumulate in vacuoles, and the $\mathrm{Na}^{+}$in the cell may act as an effective osmotic adjuster to maintain cell turgor, promoting plant growth (Khan et al., 2001). Wild plants showed a significant higher water content $(\mathrm{P} \leq 0.05)$ in the aerial tissue than the cultivated

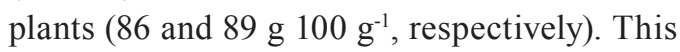
difference could be explained by the different habitats where the plants grow. For example, the wild plants were harvested from covered saltwater wetland; therefore, the plants were constantly provisioned with salt, and the tissues were overloaded with $\mathrm{Na}^{+}$. In addition, the water in wetlands evaporates, increasing the salt concentration that remains in the medium during the non-rainy season and consequently increasing the succulence of the plant tissue. On the other side, cultivated plants were exposed to semi-controlled conditions by the implementation of an artificial roof that protected the plants against extreme temperatures, wind and rain.

Table 2. Mineral analysis (FW) of wild and cultivated Sarcocornia neei plants.

\begin{tabular}{|c|c|c|}
\hline Nutrients & Wild plants & Cultivated plants \\
\hline$N\left(\mathrm{~g} 100 \mathrm{~g}^{-1}\right)$ & $1.76 \pm 0.08 \mathrm{a}$ & $1.36 \pm 0.26 \mathrm{~b}$ \\
\hline$P\left(g 100 g^{-1}\right)$ & $0.18 \pm 0.02 \mathrm{a}$ & $0.16 \pm 0.02 \mathrm{a}$ \\
\hline $\mathrm{K}\left(\mathrm{g} 100 \mathrm{~g}^{-1}\right)$ & $2.03 \pm 0.09 \mathrm{a}$ & $1.55 \pm 0.09 \mathrm{~b}$ \\
\hline $\mathrm{Ca}\left(\mathrm{g} 100 \mathrm{~g}^{-1}\right)$ & $0.63 \pm 0.07 \mathrm{a}$ & $0.53 \pm 0.05 b$ \\
\hline $\operatorname{Mg}\left(\mathrm{g} 100 \mathrm{~g}^{-1}\right)$ & $1.13 \pm 0.16 \mathrm{a}$ & $0.82 \pm 0.08 \mathrm{~b}$ \\
\hline $\mathrm{Zn}\left(\mathrm{mg} \mathrm{kg}^{-1}\right)$ & $28.48 \pm 4.71 \mathrm{a}$ & $40.98 \pm 9.80 \mathrm{a}$ \\
\hline $\operatorname{Mn}\left(\mathrm{mg} \mathrm{kg}^{-1}\right)$ & $100.38 \pm 18.27 \mathrm{a}$ & $42.00 \pm 16.09 \mathrm{~b}$ \\
\hline $\mathrm{Fe}\left(\mathrm{mg} \mathrm{kg}^{-1}\right)$ & $334.75 \pm 113.49 \mathrm{a}$ & $276.25 \pm 84.12 \mathrm{a}$ \\
\hline $\mathrm{Cu}\left(\mathrm{mg} \mathrm{kg}^{-1}\right)$ & $17.20 \pm 5.86 \mathrm{a}$ & $16.7 \pm 4.62 \mathrm{a}$ \\
\hline $\mathrm{B}\left(\mathrm{mg} \mathrm{kg}^{-1}\right)$ & $25.40 \pm 2.87 \mathrm{a}$ & $33.33 \pm 1.50 \mathrm{~b}$ \\
\hline $\mathrm{Cl}\left(\mathrm{g} 100 \mathrm{~g}^{-1}\right)$ & $15.58 \pm 0.73 \mathrm{a}$ & $15.00 \pm 1.95 \mathrm{a}$ \\
\hline $\mathrm{Na}\left(\mathrm{g} 100 \mathrm{~g}^{-1}\right)$ & $8.07 \pm 0.47 \mathrm{a}$ & $10.01 \pm 0.69 \mathrm{~b}$ \\
\hline $\mathrm{Cd}\left(\mathrm{mg} \mathrm{kg}^{-1}\right)$ & $0.04 \pm 0.08 \mathrm{a}$ & $0.32 \pm 0.15 b$ \\
\hline $\mathrm{Pb}\left(\mathrm{mg} \mathrm{kg}^{-1}\right)$ & $12.33 \pm 0.64 \mathrm{a}$ & $9.72 \pm 0.93 \mathrm{~b}$ \\
\hline As $\left(\mathrm{mg} \mathrm{kg}^{-1}\right)$ & $0.22 \pm 0.08 \mathrm{a}$ & $0.01 \pm 0.00 \mathrm{~b}$ \\
\hline
\end{tabular}

Data are expressed as the means of four repetitions. Different letters in vertical columns indicate significant differences $(\mathrm{P} \leq 0.05)$. 
Table 3. Functional characterization of wild and cultivated Sarcocornia neei plants.

\begin{tabular}{lcc}
\hline & \multicolumn{2}{c}{ Functional characterization } \\
\cline { 2 - 3 } Analysis & Wild plants & Cultivated plants \\
\hline Dietary fiber $\left({\left.\mathrm{g} 100 \mathrm{~g} \mathrm{~g}^{-1} \mathrm{DW}\right)}\right.$ & $26.98 \pm 0.03 \mathrm{a}$ & $15.88 \pm 0.06 \mathrm{~b}$ \\
Total phenolics $\left(\mathrm{mg} \mathrm{GAE} \mathrm{g}^{-1} \mathrm{DW}\right)$ & $6.13 \pm 0.24 \mathrm{a}$ & $2.85 \pm 0.24 \mathrm{~b}$ \\
$\beta$-carotene $\left(\mathrm{mg} \mathrm{g}^{-1} \mathrm{DW}\right)$ & $0.47 \pm 0.06 \mathrm{a}$ & $0.46 \pm 0.03 \mathrm{a}$ \\
Hydrophilic AC $\left(\mu \mathrm{moles} \mathrm{TE} \mathrm{g}^{-1} \mathrm{DW}\right)$ & $33.4 \pm 4.51 \mathrm{a}$ & $11.42 \pm 1.36 \mathrm{~b}$ \\
Lipophilic AC $\left(\mu \mathrm{moles} \mathrm{TE} \mathrm{g}^{-1} \mathrm{DW}\right)$ & $1.81 \pm 0.39 \mathrm{a}$ & $1.87 \pm 0.37 \mathrm{a}$ \\
Ascorbic acid $\left(\mathrm{mg} \mathrm{g}^{-1} \mathrm{DW}\right)$ & $0.55 \pm 0.06 \mathrm{a}$ & $0.9 \pm 0.54 \mathrm{a}$ \\
\hline
\end{tabular}

Data are expressed as the means of four repetitions. $\mathrm{AC}=$ antioxidant capacity. Different letters in vertical columns indicate significant differences $(\mathrm{P} \leq 0.05)$.

The nutritional profile of wild $S$. neei substantially changed with seawater cultivation, displaying higher contents of ash and crude fiber but lower protein content (Table 1). Crude fiber in both cases (wild and cultivated) was higher than in Salicornia (Lu et al., 2010). Increasing salinity level in the water tended to decrease the crude fiber (Ashour et al., 1999). During the non-rainy season, the wild plants are exposed to higher salinity levels than seawater due to water evaporation resulting in increased $\mathrm{NaCl}$ concentration.

The ash content in the aerial tissue of wild and cultivated plants was high. The results obtained in

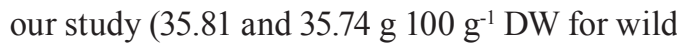
and cultivated plants, respectively) were higher than the ash values reported for some other species of Sarcocornia found in Brazil (24.98 - $31.85 \mathrm{~g}$ $100 \mathrm{~g}^{-1} \mathrm{DW}$ ) (Bertin et al., 2014). The cultivated plants accumulated more minerals (Table 2) than the wild plants probably because the cultivated plants had $20 \mathrm{~L} \mathrm{~d}^{-1}$ irrigation; the permanent income of saline water maintained a continuous availability of minerals for plants that allowed greater absorption of $\mathrm{Na}^{+}$. On the other hand, the wild plants were exposed to rainy seasons, which decreased the salinity in the soil, and non-rainy seasons, which increased the salinity.

The amount of protein (13.50 and $6.98{\mathrm{~g} 100 \mathrm{~g}^{-1}}^{-1}$ DW for wild and cultivated plants, respectively) as a leafy vegetable was low compared with cabbage, lettuce and parsley $(16.18,31.83$, and 24.17 g $100 \mathrm{~g}^{-1} \mathrm{DW}$, respectively) (Caunii et al., 2010).
The protein content was higher in wild plants than in cultivated plants (Table 1). Previously, an increased protein content in plants grown under high salinity was reported (Parks et al., 2002). Protein biosynthesis can be promoted as a result of stress response, inducing different changes in energy metabolism resulting in both short-term (attenuation of direct impacts of stress such as changes in osmotic potential and salt ion activity) and long-term stress adaptations (structural adaptations of plant cells that consequentially change plant growth and development (Kosová et al., 2013). The synthesis of several low-molecular, highly hydrophilic organic compounds as well as high-molecular hydrophilic proteins (e.g., Late Embryogenesis Abundant (LEA) proteins) which not only decrease intracellular osmotic potential but also enhance protective properties on other cellular compounds due to salinity stress. Thus, proteins play an imminent role in plant stress response because they are directly involved in the acquisition of an enhanced stress tolerance (Kosová et al., 2010). The wild plants grow under natural stress conditions such as different temperatures between seasons, coastal wind, changing soil salinity due to the rain that leaches nutrients, and root flooding. These different types of stresses probably caused an increase in protein content in the wild plants compared with the cultivated plants that were grown in a controlled environment.

The lipid content for the wild and cultivated plants did not display any significant difference $(\mathrm{P}>0.05)$, and the values were higher than the 
values reported for spinach and lettuce (Simopoulos, 2004). Increasing the seawater concentration had no effect on the lipid content as previously reported by Ventura et al. (2011). The NFE content was similar to the value of $4.48 \%$ reported by Lu et al. (2010).

\section{Mineral content}

The mineral composition of $S$. neei is displayed in Table 2. $\mathrm{Na}^{+}$and $\mathrm{Cl}^{-}$are the main ions accumulated; it is a plant that commonly grows in highsalinity environments, absorbing high amounts of minerals, especially $\mathrm{Na}^{+}$and $\mathrm{Cl}^{-}$(compared with glycophytic plants), that are mainly stored in aerial tissue (Ventura et al., 2011). S. neei absorbs heavy metals; thus, it is necessary to know the soil composition where the plant is cultivated. Heavy metals are not biodegradable and therefore have the potential for bioaccumulation (Gbaruko and Friday, 2007). A mineral analysis of the soil where the wild $S$. neei grew was performed, and non-important amounts of heavy metals $\mathrm{Cd}, \mathrm{Pb}$ and As $\left(3.28,8.35\right.$, and $0.75 \mathrm{mg} \mathrm{kg}^{-1}$, respectively) were found according to the standards of the European Commission (2001).

The data analysis showed that the $\mathrm{Mg}^{2+}, \mathrm{Ca}^{2+}$ and $\mathrm{K}^{+}$ in cultivated plants decreased, but $\mathrm{Na}^{+}$increased. $\mathrm{The} \mathrm{Na}^{+}$content in $S$. neei was very high compared with other green leafy vegetables (e.g., lettuce

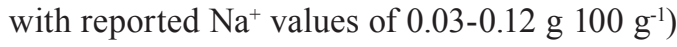
(Barzegar et al., 2007). The permanent income of saline water in cultivated plants maintained the continuous availability of minerals for plants that allowed greater absorption of $\mathrm{Na}^{+}$. Apparently, there are mechanisms for $\mathrm{Na}^{+}$transfer against other ions, but the uptake of $\mathrm{Cl}^{-}$depends on soil salt. This mechanism consists of a vacuolar compartmentalization of $\mathrm{Na}^{+}$through vacuolar $\mathrm{Na}^{+} / \mathrm{H}^{+}$ antiporters and provides an efficient mechanism to avoid the negative effects of $\mathrm{Na}^{+}$in the cytosol and maintains the osmotic potential through $\mathrm{Na}^{+}$ (and $\mathrm{Cl}^{-}$) accumulation in the vacuole to drive water uptake into cells (Apse et al., 1999).
The cultivated plants displayed lower contents of $\mathrm{K}^{+}, \mathrm{Mg}^{2+}$ and $\mathrm{Ca}^{2+}$ than the wild counterparts. These nutrients decreased in the cultivated plants possibly as a result of the competition with $\mathrm{Na}^{+}$ during uptake (Flowers and Colmer, 2008).

\section{Functional characterization}

The amount of dietary fiber in S. neei (26.98 and

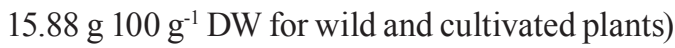
is comparable with that of some green leafy vegetables such as cabbage and lettuce (24.45 and 21.

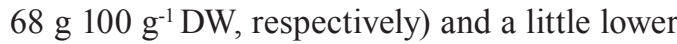
than that of some other vegetables such as spinach

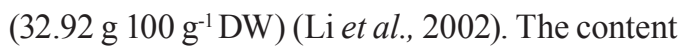
is nearly $40 \%$ of the vegetable tissue (Table 3) and represents a good, non-conventional source of dietary fiber (Valenzuela and Maiz, 2006). Wild plants had a considerably higher amount of dietary fiber (26.98 g $\left.100 \mathrm{~g} \mathrm{~g}^{-1} \mathrm{DW}\right)$ than Salicornia species (16.5 g $\left.100 \mathrm{~g}^{-1} \mathrm{DW}\right)$ (Acosta-Ruiz et al., 2011). The wild plants presented higher amounts of dietary fiber than the cultivated plant, possibly due to the exposure to stress conditions in its natural coastal ecosystem, which caused an increase of lignin and other structural carbohydrates (Moura et al., 2010) as a defense mechanism.

The total phenolics in $S$. neei (6.13 and $2.85 \mathrm{mg}$ GAE g-1 DW for the wild and cultivated plants, respectively) were lower than the values reported for other green leafy vegetables such as lettuce (16.9 $\mathrm{mg} \mathrm{GAE} \mathrm{g}^{-1}$ DW) (Tiveron et al., 2012). The content was higher in wild plants (6.13 mg GAE $\left.\mathrm{g}^{-1} \mathrm{DW}\right)$ compared with that of another species of Sarcocornia (4.32 $\mathrm{mg} \mathrm{GAE} \mathrm{g}^{-1} \mathrm{DW}$ ) (Gargouri et al., 2013). The differences between both plants (wild and cultivated) (Table 3) are probably due to the exposure to different stress conditions. According to Mamdouh et al. (2002), plants can synthesize and accumulate phenolic compounds in response to stress, and in their natural environments, plants are exposed to abiotic stresses. Additionally, the HAA, mainly represented by the phenolic compounds (Manach et al., 2005) 
was higher in wild than in cultivated plants. In natural conditions where the plant grows, the change in temperature between seasons, wind, the changing soil salinity due to rain leaching nutrients and root flooding, cause a change in the metabolism of plants, which increase their defense and therefore their antioxidant capacity. The HAA content for $S$. neei as a green leafy vegetable was lower in the wild and cultivated plants (33.4 and $11.42 \mu$ moles TE g ${ }^{-1} \mathrm{DW}$, respectively) compared with lettuce (265.35 $\mu$ moles TE $\left.\mathrm{g}^{-1} \mathrm{DW}\right)(\mathrm{Wu}$ et al., 2004).

Non-significant differences in the contents of $\beta$-carotene, ascorbic acid and LAA were found between the wild and cultivated plants (Table $3)$. The $\beta$-carotene content $\left(0.47 \mathrm{mg} \mathrm{g}^{-1} \mathrm{DW}\right)$ as a green leafy vegetable was lower than that of lettuce (0.75 $\left.\mathrm{mg} \mathrm{g}^{-1} \mathrm{DW}\right)$ (Mou, 2005). A study by Agawu (2012) showed that an increase in salinity level decreased the $\beta$-carotene content, which caused not only stomatal closure but also a decrease in stomata size and density. This effect may reduce water loss from the plants, leading to a reduction of $\mathrm{CO}_{2}$ and light-energy intake that affects photosynthesis (Iyengar and Reddy, 1996). Compared with other ecotypes of Sarcocornia (0.6-0.8 $\mathrm{mg} \mathrm{g}^{-1} \mathrm{DW}$ ) (Agawu, 2012), the content of $\beta$-carotene found in wild and cultivated $S$. neei was lower (0.46-0.47 $\left.\mathrm{mg} \mathrm{g}^{-1} \mathrm{DW}\right)$. Agawu (2012) also reported that the ascorbic acid content declined remarkably under $\mathrm{NaCl}$ stress. The ascorbic acid content in S. perennis $\left(8289 \mathrm{mg} \mathrm{g}^{-1}\right.$ DW) (Gargouri et al., 2013) was much higher than the values found in wild and cultivated $S$. neei (0.55-0.9 $\left.\mathrm{mg} \mathrm{g}^{-1} \mathrm{DW}\right)$ and comparable with other green leafy vegetables such spinach (0.22-0.31 mg $\mathrm{g}^{-1} \mathrm{DW}$ ) (Favell, 1998). Finally, the LAA in wild and cultivated plants (1.81 and $1.87 \mu$ moles TE $\mathrm{g}^{-1}$ $\mathrm{DW}$, respectively) as a green leafy vegetable were lower than the values reported for lettuce (23.26 $\mu$ moles TE $\mathrm{g}^{-1} \mathrm{DW}$ ) (Wu et al., 2004).

The results of cultivated plants of $S$. neei (seawater) showed that this plant could be domesticated and potentially be consumed as a green leafy vegetable with a good source of ash, crude fiber and NFE. In general, the wild plants presented higher amounts of compounds or metabolites (e.g., polyphenols, dietary fiber, and proteins) involved in defense under stress conditions (e.g., soil salinity, rain, wind, and temperature extremes). The differences are mainly structural (fiber and proteins) or due to the synthesis of antioxidant molecules (phenols, HAA). The cultivation of S. neei under highly stressful conditions might encourage the synthesis of valuable compounds for human health, raising the nutritional and functional value of this halophyte.

\section{Acknowledgments}

The authors thank the Regional Government of Valparaíso (Chile). This research was supported by a FIC BIP 30154272 grant. The authors wish to thank Mrs. Cecilia Herrera for her technical assistance.

\section{Resumen}

J. Riquelme, J.O. Olaeta, L. Gálvez, P. Undurraga, C. Fuentealba, A. Osses, J. Orellana, J. Gallardo y R. Pedreschi. Caracterización nutricional y funcional de Sarcocornia neei silvestre y cultivada presente en Chile. Cien. Inv. Agr. 43(2):283-293. La halófita Sarcocornia neei es un vegetal que crece en las costas de la V región en Chile. Estudios relacionados con su valor nutricional y funcional bajo condiciones silvestres y cultivadas no están disponibles. Por lo tanto, en este estudio se realizó una caracterización nutricional (proximal completo, análisis mineral y de fibra dietaria) y funcional (fenoles totales, $\beta$-caroteno, actividad antioxidante hidrofílica (AAH) y lipofílica (AAL) y ácido ascórbico) en las plantas silvestres y cultivadas. 
En las plantas silvestres se visualizó una mayor cantidad de compuestos relacionados con el mecanismo de defensa del estrés tales como fenoles totales, proteínas, fibra dietaria y cenizas. El análisis mineral reveló que los iones mayormente acumulados son $\mathrm{Na}^{+}$y $\mathrm{Cl}^{-}$en las plantas silvestres y cultivadas, siendo mayor en las plantas cultivadas. La caracterización funcional reveló una mayor cantidad de fibra dietaria, fenoles totales y AAH en las plantas silvestres que en las plantas cultivadas. Contenidos similares de $\beta$-caroteno, AAL y ácido ascórbico fueron encontrados en las plantas silvestres y cultivadas. Los resultados de este análisis proporcionan evidencia sobre el potencial de Sarcoconia neei para ser consumida como un vegetal de hoja verde con importantes cantidades de nutrientes principales y metabolitos funcionales.

Palabras clave: Agua de mar, análisis proximal, antioxidantes, fibra dietaria, sustentabilidad.

\section{References}

Acosta-Ruiz, M., J. Paniagua-Michel, J. Olmos-Soto, and E. Paredes-Escalona. 2011. Primer registro de la utilización de harinas de Salicornia bigelovii y Scomber japonicus en dietas prácticas para el cultivo super-intensivo de camarón Litopenaeus stylirostris. Latin American Journal of Aquatic Research 39: 409-415.

Adiveter. 2005. Legislación de la Unión europea de Contaminantes Químicos en productos Alimentarios. Available online at: http://www.adiveter. com/ftp_public/articulo1748.pdf (Website accessed: August 23, 2015).

Agawu, E. 2012. Comparison between Salicornia and Sarcocornia ecotypes to optimize yield for vegetable production applying highly saline irrigation. Thesis submitted in partial fulfilment of the requirements for the degree of "Master of Science”. Ben Gurion University of the Negev, Beer Sheva, Israel. 139 pp.

Apse, M.P., G.S. Aharon, W.A. Snedden, and E. Blumwald. 1999. Salt tolerance conferred by overexpression of a vacuolar $\mathrm{Na}^{+} / \mathrm{H}^{+}$antiport in Arabidopsis. Science 285: 1256-1258.

Ashour, N., S. Arafat, A. Abd El-Haleem, M. Serage, S. Mandour, and B. Mekki. 1999. Growing halophytes in Egypt for forage production and desertification control. Bull. N.R.C. Egypt 24: 349-360.

Barzegar, M., F. Erfani, A. Jabbari, and M.R. Hassandokht. 2007. Chemical composition of 15 spinach (Spinacea oleracea L.) cultivars grown in Iran. Italian Journal of Food Science 19: 309 318.

Bertin, R.L, L.V. Gonzaga, G.D. Borges, M.S. Azevedo, H.F. Maltez, M. Heller, G.A. Micke, L.B. Tavares, and R. Fett. 2014. Nutrient composition and, identification/quantification of major phenolic compounds in Sarcocornia ambigua (Amaranthaceae) using HPLC-ESI-MS/MS. Food Research International 55: 404-411.

Bustan, A., D. Pasternak, I. Pirogova, M. Durikov, T.T. de Vries, S. Meccawi, and A.A. Degen. 2005. Evaluation of saltgrass as a fodder crop for livestock. Journal of the Science of Food and Agriculture 85: 2077-2084.

Caunii, A., R. Cuciureanu, A.M. Zakar, E. Tonea, and C. Giuchici. 2010. Chemical composition of common leafy vegetables. Studia Universitatis "Vasile Goldiş". Seria Ştiinţele Vieţii 20: 45-48.

Chen, Y.W., S.W. Wu, K.K. Ho, S.B. Lin, C.Y. Huang, and C.N. Chen. 2008. Characterization of Taiwanese propolis collected from different locations and seasons. Journal of the Science of Food and Agriculture 88: 412-419.

Davy, A.J., G.F. Bishop, H. Mossman, S. RedondoGómez, J. Castillo, E Castellanos, T.Luque, and M.E. Figueroa. 2006. Biological flora of the British Isles: Sarcocornia perennis (Miller) A.J. Scott. Journal of Ecology 94: 1035-1048.

Eganathan, P., H.M.S. Subramanian, R. Latha, and C.S. Rao. 2006. Oil analysis in seeds of Salicornia brachiata. Industrial Crops and Products 23: 177-179. 
European Commission. 2001. Survey of wastes spread on land. Official Publications of the European Communities. Luxembourg, Luxembourg. $554 \mathrm{pp}$.

Favell, D. 1998. A comparison of the vitamin C content on fresh and frozen vegetables. Food Chemistry 62: 59-64.

Flowers, T.J. and T.D. Colmer. 2008. Salinity tolerance of halophytes. New Phytologists 179: $945-$ 963.

Gargouri, M., C. Magné, X. Dauvergne, R. Ksouri, A. El Feki, A. Giroux-Metges, and H. Talarmin. 2013. Cytoprotective and antioxidant effects of the edible halophyte Sarcocornia perennis L. (swampfire) against lead-induced toxicity in renal cells. Ecotoxicology and Environmental Safety 95: 44-51.

Gbaruko, B.C., and O.U. Friday. 2007. Bioaccumulation of heavy metals of some fauna and flora. International Journal of Environmental Science and Technology 4: 197-202.

Isabelle, M., B.L. Lee, M.T. Lin, W.P. Koh, D. Huang, and C.N. Ong. 2010. Antioxidant activity and profiles of common vegetables in Singapore. Food Chemistry 120: 993-1003.

Iyengar, E.R.R., and M.P. Reddy. 1996. Photosynthesis in highly salt tolerant plants. p. 897-909. In: Pesserkali, M. (ed.). Handbook of photosynthesis. Marshal Dekar, Baten Rose, USA.

Johns, T., and P.B. Eyzaguirre. 2006. Linking biodiversity, diet and health in policy and practice. Proceedings of the Nutrition Society 65: 182189.

Khan, M.A., B. Gul, and D.J. Weber. 2001. Effect of salinity on the growth and ion content of Salicornia rubra. Soil Science and Plant Analysis 32: 2965-2977.

Kosová, K., I.T. Prášil, and P. Vítámvás. 2013. Protein contribution to plant salinity response and tolerance acquisition. International Journal of Molecular Sciences 14: 6757-6789.

Kosová, K., P. Vítámvás, and I.T. Prášil. 2010. The role of dehydrins in plant stress response. p. 239285. In: Pessarakli, M. (ed). Handbook of Plant and Crop Stress, 3rd Ed. CRC Press, Taylor and Francis: Boca Raton, FL, USA.
Li, B., K. Andrews, and P. Pehrsson. 2002. Individual sugars, soluble, and insoluble dietary fiber contents of 70 high consumption foods. Journal of Food Composition and Analysis 15: 715-723.

Lu, D.H, M. Zhang, S.J. Wang, J.L. Cai, X. Zhou, and C.P. Zhu. 2010. Nutritional characterization and changes in quality of Salicornia bigelovii Torr. during storage. LWT - Food Science and Technology 43: 519-524.

Mamdouh, M., Y. Mahmoud, E. Omar, and B. Zeinab. 2002. Kinetin regulation of growth and secondary metabolism in waterlogging and salinity treated Vigna sinensis and Zea mays. Acta Physiologia Plantarum 24: 19-27.

Manach, C., G. Williamson, C. Moran, A. Scalbert, and C. Remesy. 2005. Bioavailability and bioefficacy of polyphenols in humans. I. Review of 97 bioavailability studies. American Journal of Clinical Nutrition 81: 230-242.

Manousaki, E., and N. Kalogerakis. 2011. Halophytes present new opportunities in phytoremediation of heavy metals and saline soils. Industrial and Engineering Chemistry Research 50: 656-660.

Mou, B. 2005. Genetic variation of beta-carotene and lutein contents in lettuce. Journal of the American Society for Horticultural Science 130: 870876.

Moura, J., C. Bonine, J. de Oliveira Fernandes Viana, M. Dornelas , and P. Mazzafera. 2010. Abiotic and biotic stresses and changes in the lignin content and composition in plants. Journal of Integrative Plant Biology 52: 360-372.

Odriozola-Serrano, I., T. Hernandez-Jover, and O. Martin-Belloso. 2007. Comparative evaluation of UV-HPLC methods and reducing agents to determine vitamin $\mathrm{C}$ in fruits. Food Chemistry 105: 1151-1158.

Official Methods of Analysis of AOAC International. 1984. 17th Edition.

Parks, G.E, M.A. Dietrich, and K.S. Schumaker. 2002. Increased vacuolar $\mathrm{Na}^{+} / \mathrm{H}^{+}$exchange activity in Salicornia bigelovii Torr. In response to $\mathrm{NaCl}$. Journal of Experimental Botany 53: 10551065. 
Proteggente, A.R., A.S. Pannala, G. Paganga, L. Van Buren, E. Wagner, S. Wiseman, F. Van de Put, C. Dacombe, and C.A. Rice-Evans. 2002. The antioxidant activity of regularly consumed fruit and vegetables reflects their phenolic and vitamin C composition. Free Radical Research 36: 217-233.

Reyes, L.F., J.E. Villarreal, and L. Cisneros-Zevallos. 2007. The increase in antioxidant capacity after wounding depends on the type of fruit or vegetable tissue. Food Chemistry 101: 1254-1262.

Sadzawka A. 2006. Métodos de análisis de aguas para riego. INIA. Santiago, Chile. Serie Actas INIA $\mathrm{N}^{\circ} 37.332 \mathrm{pp}$.

Sadzawka A., M.A. Carrasco, R. Demanet, H. Flores, R. Grez, M.L. Mora, and A. Neaman. 2007. Métodos de análisis de tejidos vegetales. INIA. Segunda Edición. Santiago, Chile. Serie Actas INIA N ${ }^{\circ} 40.139$ pp.

Sadzawka A., R. Grez, M.A. Carrasco, and M.L. Mora. 2004. Métodos de análisis de tejidos vegetales. INIA. Santiago, Chile.

Schmidt - Hebbel, H. 1981. Avances en Ciencia y Tecnología de los Alimentos. Merck Química Chilena, Santiago, Chile. 265 pp.

Scott, A.J. 1978. Reinstatement and revision of Salicorniaceae J. Agardh (Caryophyllales). Botanical Journal of the Linnean Society 75: 357-374.

Shetty, K., O.F. Curtis, R.E. Levin, R. Wikowsky, and W. Ang. 1995. Prevention of verification associated with in vitro shoot culture of oregano
(Origanum vulgare) by Pseudomonas spp. Journal of Plant Physiology 147: 447-451.

Simopoulos, A.P. 2004. Omega-3 fatty acids and antioxidants in edible wild plants. Biological Research, 37: 263-277.

Tiveron, A.P., P.S. Melo, K.B. Bergamaschi, T.M.F.S. Vieira, M.A.B. Regitano-d'Arce, and S.M. Alencar. 2012. Antioxidant activity of Brazilian vegetables and its relation with phenolic composition. International Journal of Molecular Science 13: 8943-8957.

Valenzuela, A., and A. Maiz. 2006. Rol de la fibra dietética en la nutrición enteral. Revista Chilena de Nutrición 33: 342-351.

Ventura, Y., W.A. Wuddineh, M. Myrzabayeva, Z. Alikulov, I. Khozin-Goldberg, M. Shpigel, T.M. Samocha, and M. Sagi. 2011. Effect of seawater concentration on the productivity and nutritional value of annual Salicornia and perennial Sarcocornia halophytes as leafy vegetable crops. Scientia Horticulturae 128: 189-196.

Wu, X., L. Gu, J. Holden, D.B. Haytowitz, S.E. Gebhardt, G. Beecher, and R.L. Prior. 2004. Development of a database for total antioxidant capacity in foods: a preliminary study. Journal of Food Composition and Analysis 17: 407-422.

Zia, S., T. Egan, and M.A. Khan. 2008. Growth and selective ion transport of Limonium stocksii Plumbaginacea under saline conditions. Pakistan Journal of Botany 40: 697-709. 
